\title{
EFFECT OF CLINICAL PATHWAY OF POSTOPERATIVE NURSING CAREON IMPROVING POSTOPERATIVE OUTCOMES FOR WOMEN UNDERGOING HYSTERECTOMY
}

\author{
Hanaa Elsayed Shahin ${ }^{1}$, Amal Khalifa Khalii ${ }^{2}$,Nagat Salah Shalaby ${ }^{3}$
}

Assistant Professor of Maternal and Newborn Health Nursing, Faculty of Nursing, Menoufia University, Egypt ${ }^{1}$

Lecturer ofMaternal and Newborn Health Nursing, Faculty of Nursing, Menoufia University, Egypt ${ }^{2}$

Assistant Professor of Maternity, Obstetrical and Gynecological Nursing, Faculty of Nursing, Port Said University,, Egypt ${ }^{3}$

\begin{abstract}
Background: Utilization of a multidisciplinary clinical pathway during care of women undergoing hysterectomy is considered to be more effective during women' management than routine hospital care.Aim: This study was conducted to investigate the effect of clinical pathway of postoperative nursing care on improving postoperative outcomesfor women undergoing hysterectomy. Design: A quasi experimental design (study and control group). Settings: The gynecology and obstetrics departments at two hospitals affiliated to University Hospital and Shebin El-Kom teaching hospital, Menoufia Governorate. Subjects: 100 women who are undergoing hysterectomywere selected. Tools: three instruments were used for data collection;a structured interviewing, numeric pain intensity scaleandpatient satisfaction record.Results: The current study shows that women underwent hysterectomy in the study group were significantly more likely to experience less mean pain score, lesser need for analgesiaand Significant differences in the length of stay were observed compared to those in the control group.Significant differences in the early oral intake, postoperative bowel mobility and need to antiemetic drugswere observed between the study and the control groups. Concerning women's satisfaction related to the care provided,the score given was mostly satisfied and neutral. Conclusion: application of clinical pathway improving postoperative pain successfully, short length of stay postoperative outcomes related to early ambulation, early oral intake, and bowel mobility, hours to remove catheters and drains and patient satisfaction. Recommendation: Sit is recommended to generalize application of clinical pathways in other clinical areas to improve patient outcomes and reduce postoperative complications.
\end{abstract}

Keywords: Clinical pathway, Hysterectomy, Nursing care, Postoperative outcome. 


\section{INTRODUCTION}

Hysterectomy is one of the world's most prevalent gynecological procedures, with around 600,000 women undergoing hysterectomy every year(Wright et al, 2013). Hysterectomies account for 50 percent of gynecological surgical procedures in women over 35 years of age worldwide.With the steady rise in the elderly population, the occurrence of hysterectomies is growing and may also occur in young patients(Mansuria et al., 2016).For clinical conditions such as uterine fibroids, endometriosis, pelvic support problems (i.e. uterine prolapse), abnormal uterine bleeding, cancer, and chronic pelvic pain, hysterectomies are usually performed as a final treatment choice(Wright et al., 2013).

Women undergoing hysterectomy require specific standardized care in either the acute settings or recovery department (Liu et al., 2012 \& Chinese Ministry of Health and Family Planning, 2013), which is more patient-centered and organizes the care management process. The main method of reorganizing a care process is the development and application of the clinical pathway, which may eliminate differences in care management and enhance the outcomes of women (Lam et al., 2014 \&Sarna et al., 2013). Clinical pathways are commonly utilized in hospitals to control treatment processes through surgical specialties to increase the effectiveness of care (Qualtrics Survey Service, 2017), and minimize the average length of stay of women by 40 percent for hysterectomy surgery(Stang et al, 2014).In addition clinical pathways optimize the multi health care team's knowledge and reduce practice inconsistency as it has a positive impact on team work, involving: improved team coordination, better professional documentation, and decrease risk of burnout and tasks orientation (Desai et al., 2016).

The hysterectomy pathway should be developed through the cooperative endeavor of the health care givers such as physicians, nurses, pharmacists and others to increase the quality and value of women's care (Borah et al., 2016).It combines nursing care plans, medical care, and other health care-related into a single care plan that precisely describes a patient's planned success and outcomes across the healthcare system (Hripcsak et al., 2016).It is the responsibility of nurses to initiate and upgrade the professional pathway used to guide and assess 
women's healthcare and to ensure that the various best practice events take place in a manner that a multidisciplinary team will adopt and end the chain of workers included in providing care ((Mansuria et al, 2016 and Centre for Policy on Ageing, 2015).

Since nurses play a crucial role in the management of women undergoing hysterectomy by involvement in the design and application of the care pathway in all facets of the clinical pathway(Schrijvers, Hoorn and Huiskes, 2012).Thus, the coordination and application of clinical pathway strategies for nurses unique to women undergoing hysterectomy that include management courses where the clinical pathway tends to be an effective way to provide nurses with useful knowledge and practice on women's care during women's hospitalization to reduce their hospital stay (DE BLESER et al., 2006).

For the team and nursing staff to work, the clinical pathway is very useful when defining the standard of predicted performance within a time table; it allows the nurse to assess the success of women with respect to any variances from the usual results (Hripcsak et al., 2016). Nursing workers must consider their positions by ensuring that best performance and best care for women are integrated into extremely important pathways (Borah et al., 2016). In order to be able to deliver health managementin a consistent manner that enhances the clinical conditions of patients, they should also be involved in the development, delivery and continuous review of any clinical care pathway stage for women (Ghant et al., 2014).

\section{Significance of the study:-}

Improved clinical pathways that carried out in gynecologic surgery by a maternity nurse could lead to a substantial improve in postoperative performance. These include quicker gastrointestinal function return, outstanding pain relief with dramatically reduced prescription needs, decreased hospital stay period, excellent patient satisfaction, and combined with substantial reductions in complications and readmission rates (Abd El-Razek, 2018). In hysterectomy surgery, few groups tested improved healing process, and most cohorts were small and few patients with benign conditions were included (Rotter, de Jong, Lacko SE, et al, 2019).Meanwhile, in Menoufia, no research on this problem have been done. Therefore, this research seeks to investigate the effect of clinical pathway of 
postoperative nursing care on improving postoperative outcomes for women undergoing hysterectomy.

\section{Operational Definitions:}

Clinical pathway theoretically defined as way of setting out a process of best practice to be followed in the management of a patient or client with a particular condition or with particular needs (Hripcsak et al., 2016). Also, it is known that a multidisciplinary care plan method based on an evidence-based practice for a certain patients with a expected outcome of clinical course, in which the different duties done by the professional staff included in the patient participation in his/ her management plan, which are known, optimized and outcomes are related to specific interventions (Schrijvers, Hoorn and Huiskes, 2012). A clinical pathway was operationally known to be a care plan in which an intervention which based on best practice took place (detailed instruction of the best practice on preoperative and postoperative nursing intervention given to the maternity nurses and assessment of women, application of postoperative nursing procedure and providing education) with monitoring outcomes.

Postoperative outcomes were operationally refers to the duration of hospitalization, postoperative pain, post-operative complications as; abdominal cramps, distension, constipation and women satisfaction.

\section{AIM OF THE STUDY:}

Investigate the effect of clinical pathway of postoperative nursing care on improving postoperative outcomes for women undergoing hysterectomy.

\section{Research hypotheses}

1. Women undergoing hysterectomy who receive clinical pathway will have shorter duration of hospitalization and less postoperative pain than those who do not receive.

2. Women undergoing hysterectomy who receive clinical pathway will suffer from less post-operative complications as; abdominal cramps, distension and constipation than those who do not receive.

3. Women undergoing hysterectomy surgery who receive clinical pathway will be more satisfied than those who do not receive. 


\section{SUBJECTS AND METHOD:}

Research design: A quasi-experimental research design was used in the present research.

Settings: This study was conducted in the obstetrics and gynecology departments at two hospitalsaffiliated to University Hospital and Shebin El-Kom teaching hospital, Menoufia Governorate, Egypt.

Sample: A purposive sample of 100 women were recruited in this study. The cases were then randomly assigned into two groups (study and control group). Each of the 100 women was asked to pick a piece of paper containing a number; those who selected number 1 was assigned to the study group and those who selected number 2 were assigned to the control group. This technique was used to avoid sample contamination and bias.

The inclusion criteria: women age $35>45$ years of age, undergoing hysterectomy, and free from chronic diseases.

The exclusion criterion: women with previous or coexisting cancer, women with severe underlying disease, such as serious circulatory or respiratory disorders, renal or liver dysfunction.

Sample Size: sample size was calculate by the researchers utilizing the Epi statistical program from the Open Source Statistics for Public Health. The assumptions were: a two sided, confidence level of $95 \%=1-\alpha$; a power $(1-\beta)$ or (\% chance of detecting) of $80 \%$; ratio of sample size, unexposed (control) / exposed (study group) $=1 \%$ of unexposed with outcome $=5 \%$.

Total sample size were 100 women undergoing hysterectomy The sample was divided into two groups:

Study group: composed of 50 women managed by clinical pathway management.

Control group: composed of 50 women managed by routine pre and postoperative care of the hospital.

Tools of data collection: Data were collected through using the following tools:

Tool (I): A structured interviewing: It was developed by the researchers after reviewing of related literature (Qualtrics Survey Service, 2017, Desai et al., 2016 and Hripcsak et al, 2016). It was divided into two parts: 
Part I: Socio- demographic data: it included data about age of the women, education level, occupationand income, obstetric history such as gravida, para, abortions,...etc, present gynecological history include (chief complain, medical diagnosis, time onset of the current problem,....etc.

Part II. Assessment sheet: This requires the physical examination (general appearance, vital signs, abdominal examination, etc.). Preoperative data including (pre-operative planning, informed consent, pre-operative counselling and medical care), patient record and pathway checklist were developed and used post-operatively (vital signs monitoring, early post-operative diet monitoring) for all women, respiratory care, mobilization, bladder and bowel mobility and drain....etc, postoperative hypotension, mobilization, removal of urinary catheters, return of gastrointestinal functions, pain management, duration of hospital stay and morbidity. Return of bowel activity, frequency of vomiting, pain management is the key findings from which the distinction was rendered between the study and control group.

Tool (II): Numeric Pain Intensity Scale. Zero up to 10 pain scale is used to assess the pain degree $\&$ severity. A simple assessment tool start of 0 on one end which representing no pain to a $10 \mathrm{~cm}$ line with on the other end, $(1: 3$ refers to mild pain), (4:6 refers to moderate pain), (7:10 refers to severe pain) (Abd ElRazek, 2018).

Tool (III): Patient satisfaction record adopted from RAJESWAR, (2011) was used for the study group at the end of the program which evaluates 7 items: (Information nurse was given- Ease of getting information-Information given by nurse -Skill and competence of nurse -Concern and caring by nurse -Privacy Discharge instructions).

Scoring system: With regard to the performance conducted for the control and analysis group by nurses or the researcher, a correct answer was scored 1 and the incorrect zero for each part, summing up the scores of the items and dividing the total by the number of items, giving a mean score for the part. The findings were interpreted into a percentage score, and mean and natural deviations were measured.Women consider not satisfied with the quality of nursing care if the 
total score was from 1-9; consider neutral if total score=10 and consider satisfied if total score $=11-21$.

\section{Validity :}

The developed instruments were delivered to a jury expertise included 5 experts in the field of Maternal and Newborn Health Nursing and doctors specialized in Obstetrics and Gynecology for its comprehensive content material, their point of view were elicited concerning instruments format, consistency and scoring system. Necessary modifications were done based on the jury notes.

\section{Reliability:}

The reliability for the research tools was done utilizing Alpha Cronbach's coefficient to check the internal consistency of its items, it was 0.861 for instrument (I), 0.742 for instrument (II) and 0.82 for instrument (III).

Administrative design: An official letter requesting permission to conduct the study was obtained before embarking the study from the Faculty dean of Nursing, Menoufia University to the Directors of each study setting. This letter was included the purpose of the study in order to get the permission and help for collection of data.

Ethical considerations: The researcher introduced herself to the participating women and explained the purpose of the study and its nature to obtain their acceptance to be recruited in the study as well as to gain their cooperation. Also, approaches to ensuring ethics were considered in the study regarding confidentiality and informed consent. Confidentiality was achieved by the use of locked sheets with the names of the participants replaced by numbers. All participants were informed that the information they provided during the study would be kept confidential and used only for statistical purpose and after finishing the stud. The findings would be presented as a group data with no personal participant's information remained. After explanation prior to enrollment in the study, informed consent was obtained verbally from all women.

Pilot study: A pilot study was conducted to test the research instruments. It was applied on $10 \%$ of the total sample size (10 women undergoing hysterectomy) to test the feasibility and applicability of the instruments, evaluate the study plan and 
to discover any barriers that may be faced during the duration of data collection; accordingly, needed modifications were done.The study instruments were revised, redesigned and rewritten according to the obtained results and acceptance of final form.

Procedure for data collection:The actual fieldwork was carried out from the beginning of September 2020 up to the end of December, 2020. The researchers were available in the study settings three days/week, at the morning shift from 8.00 Am to $2.00 \mathrm{Pm}$. The researchers obtained an informed consent from every woman about her participation. The researchers addressed themselves to the medical and nursing staff members. The researchers clarified the scope of the study and the intent and demanded cooperation. Women have been informed that no immediate or possible injury would be caused to them by the study maneuver and specialist assistance wouldbe given if necessary.

\section{The researchers started to collect data through the following phases:}

Assessment phase: The researcher studied local and international literature during this process to obtain more information about the subjects of the research. This also contributed in the development of the tools of study. The method was then prepared and tested using the opinions of experts. After focused review of the relevant literature, the structured interviewing and assessment sheet were formed by the researchers. Then an evidence-based recommendation was prepared for women undergoing hysterectomy on the clinical pathway during pre and postoperative nursing care. The clinical pathway team involved in women's healthcare was held in separate sessions to clarify the clinical pathway in summarized and easy way and highlight the key points to be performed by every surgeon, anaesthesiologist, a clinical nurse and pharmacist.

Planning phase: Relevant clinical pathway activities were prepared by the researchers; women's examination quickly within four hours of admission,

preoperative planning within four hours, postoperative management (in the recovery room, on the day of surgery) and pre-discharge orders, and home hysterectomy care.

Implementation phase: All women in both groups were interviewed used tool I (a structured interview). Personal interview was done for both groups and it took 
10 minutes for each one. With regard to the control group, the researchers' role was only to observe and report the routine activities undertaken by the nurses with regard to pre- and post-operative patient care. However, they incorporated the nursing care protocol for patients in the research group, which incorporates all aspects of the main elements of clinical pathway care postoperatively during the time of hospitalization before discharge from the hospital.

Evaluation Phase: This process began immediately after the surgery, in which the distinction between the study and the control group noted all the parameters of clinical pathway management and its effect on the postoperative outcomes described above.

Data analysis: All collected data were, coded, tabulated and subjected to statistical analysis using statistical Package SPSS in general (version 22), and Microsoft office Excel for data entry and graphs designing. Results expressed as Mean and SD using $t$ test. A probability level of $p$-value $\leq 0.05$ was adopted as a level of significance for testing the research hypotheses.

\section{RESULTS:}

Table (1): observed that there was no statistically significant difference between clinical pathway group and control groups regarding the socio-demographic characteristics.

Table (2):shows women under wenthy sterectomy operationin the study group were significantly more likely to have no vomiting compared to those in the control group $(\mathrm{P}=<0.001)$. Thus few number4(11.9\%) wereinneed to antiemetic comparedto $38.6 \%$ in the control group. As for the level of pain encountered by women during the postoperative period, the same table revealed that women in the study group experience dlessmean score compared to those in the control group (8.4 \pm 0.9 vs.8.7 \pm 0.8 respectively), thust hey showed less erneed for analgesia $(1.9 \pm 1.1$ vs. $2.4 \pm 0.9$ respectively) with statistical significant difference.

Table (3):shows that women in the study group were significantly $(\mathrm{P}=<0.001)$ more likely to start oral fluids within the first 10 hours after the operation

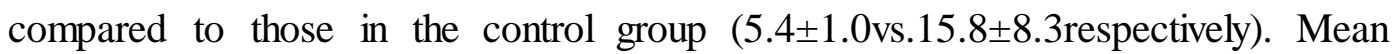
while, they received ahigher mean amount of oralfluids 
(188.6 \pm 55.2 vs.129.6 \pm 60.9 respectively) and them ajority of them $(60.0 \%)$ begun regular diet within the first 24 hours after the operation compared to those in the control group (20.0\%). Differenceobserved is statistically significant.

Table (4): points to a statistically significant difference between the study and control groups concerning the time of removing bladder catheter and drains $(\mathrm{p}<0.001)$. The mean time of removal of both catheter and drains was lesser in the study group than those in the control group $(15.3 \pm 5.7 \& 45.1 \pm 5.6$ vs. 20.5 $\pm 10.9 \& 66.2 \pm 27.9$ respectively). Moreover, women in the study group were more likely to have lesser mean time of first bowel sounds, first passage of flatus, and first passage of stool after surgery $(3.7 \pm 0.9,6.3 \pm 1.0$ and $10.5 \pm 1.9$ vs. $6.9 \pm 1.1,13.2 \pm 1.4$ and $27 \pm 2.4$ hours respectively). Differences observed are statistically significant $(\mathrm{p}=<0.001 *)$.

Table (5): reveals that women in the study group were less likely to suffer from complications as; abdominal cramps, distension and constipation compared to those in the control group.

Figure (1): shows that the mean duration of hospitalization in the study group was significantly shorter than those in the control group. Differences observed is highly significant ( $T$ test $6.718 * \& \mathrm{p}<0.001$ ).

figure (2): Describes the women satisfaction related to the care provided to the study group (clinical pathway nursing management). Rating was mostly satisfied and neutral (35.7\% and 57.2 respectively) and less than one tenth who gave the score of dissatisfied $(7.1 \%)$ to the 7 parameters showing patient's satisfaction. 
Table (1): Distribution of the Women Undergoing Hysterectomy according to Their Socio-Demographic Characteristics $(\mathrm{N}=100)$

\begin{tabular}{|c|c|c|c|c|c|c|}
\hline \multirow[t]{2}{*}{ Variables } & \multicolumn{2}{|c|}{$\begin{array}{l}\text { Study Group } \\
\qquad(\mathbf{N}=\mathbf{5 0})\end{array}$} & \multicolumn{2}{|c|}{$\begin{array}{l}\text { Control Group } \\
\qquad(\mathrm{N}=\mathbf{5 0})\end{array}$} & \multicolumn{2}{|c|}{ Chi square test } \\
\hline & No. & $\%$ & No. & $\%$ & $x^{2}$ & $\mathrm{p}$ \\
\hline \multicolumn{7}{|l|}{ Age(years) } \\
\hline$<35$ & 10 & 20.0 & 5 & 10.0 & \multirow{3}{*}{3.902} & \multirow{3}{*}{0.142} \\
\hline $35-45$ & 20 & 40.0 & 15 & 30.0 & & \\
\hline$>45$ & 20 & 40.0 & 30 & 60.0 & & \\
\hline Mean \pm SD & \multicolumn{2}{|c|}{$43.1 \pm 7.7$} & \multicolumn{2}{|c|}{$45.1 \pm 5.9$} & $1.588^{*}$ & 0.115 \\
\hline \multicolumn{7}{|l|}{ Educationallevel } \\
\hline Illiterate & 2 & 4.0 & 4 & 8.0 & \multirow{5}{*}{4.660} & \multirow{5}{*}{0.324} \\
\hline Read/write & 15 & 30.0 & 7 & 14.0 & & \\
\hline Basic & 13 & 26.0 & 12 & 24.0 & & \\
\hline Secondary & 11 & 22.0 & 14 & 28.0 & & \\
\hline High & 9 & 18.0 & 13 & 26.0 & & \\
\hline \multicolumn{7}{|l|}{ Marital status } \\
\hline Married & 30 & 60.0 & 37 & 74.0 & \multirow{3}{*}{5.308} & \multirow{3}{*}{0.151} \\
\hline Widow & 8 & 16.0 & 9 & 18.0 & & \\
\hline Single & 7 & 14.0 & 1 & 2.0 & & \\
\hline \multicolumn{7}{|l|}{ Job } \\
\hline Housewife & 30 & 60.0 & 37 & 74.0 & \multirow[t]{2}{*}{1.348} & \multirow[t]{2}{*}{0.246} \\
\hline Working & 20 & 40.0 & 13 & 26.0 & & \\
\hline
\end{tabular}


Table(2):Distribution of the Women Undergoing Hysterectomy According tothePostoperative Complications $(\mathrm{N}=100)$

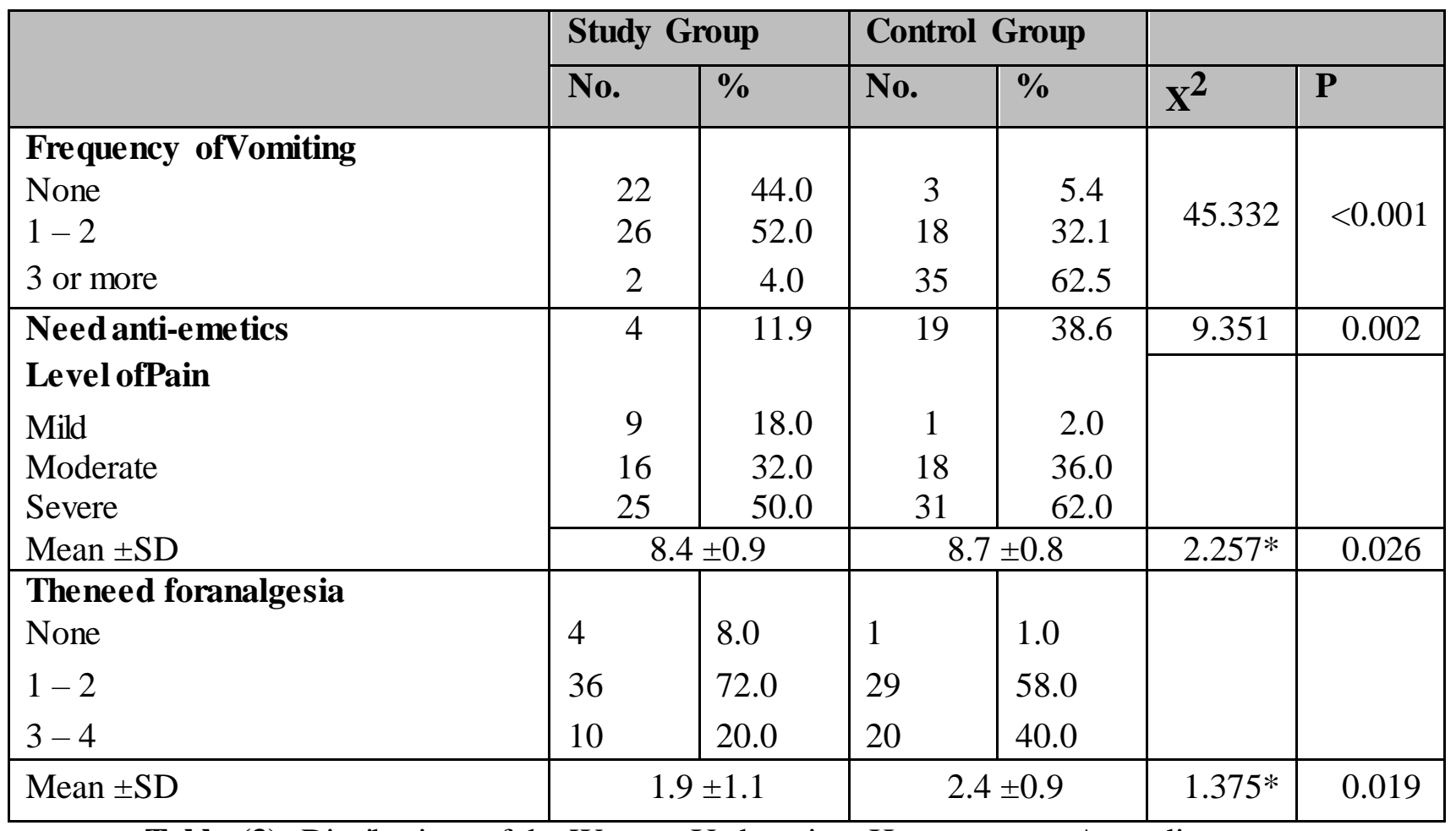

Table (3): Distribution of the Women Undergoing Hysterectomy According to their Postoperative Nourishment $(\mathrm{N}=100)$

\begin{tabular}{|c|c|c|c|c|c|c|}
\hline \multirow[t]{2}{*}{ Variables } & \multicolumn{2}{|c|}{$\begin{array}{l}\text { Study Group } \\
\qquad(\mathbf{N}=\mathbf{5 0})\end{array}$} & \multicolumn{2}{|c|}{$\begin{array}{l}\text { Control Group } \\
\qquad(\mathbf{N}=\mathbf{5 0})\end{array}$} & \multicolumn{2}{|c|}{ Chi square test } \\
\hline & No. & $\%$ & No. & $\%$ & $x^{2}$ & $\mathbf{P}$ \\
\hline Initiation of oral fluids (hours) & & & & & & \\
\hline 10 orless & 30 & 60.0 & 4 & 8.0 & & \\
\hline $11-20$ & 20 & 40.0 & 23 & 46.0 & 48.913 & $<0.001$ \\
\hline$>20$ & 0 & 0.0 & 23 & 46.0 & & \\
\hline Mean \pm SD & \multicolumn{2}{|c|}{$5.4 \pm 1.0$} & \multicolumn{2}{|c|}{$15.8 \pm 8.3$} & $9.279 *$ & $<0.001$ \\
\hline \multicolumn{7}{|l|}{$\begin{array}{l}\text { Intake amount of oral fluids } \\
\text { (liter) }\end{array}$} \\
\hline$<100$ & 1 & 1.8 & 10 & 20.0 & & \\
\hline $100-200$ & 36 & 72.0 & 37 & 74.0 & & \\
\hline$>200$ & 13 & 26.0 & 3 & 5.4 & 17.320 & $<0.001$ \\
\hline Mean \pm SD & \multicolumn{2}{|c|}{$188.6 \pm 55.2$} & \multicolumn{2}{|c|}{$129.6 \pm 60.9$} & $6.401 *$ & $<0.001$ \\
\hline \multicolumn{7}{|l|}{$\begin{array}{llll}\begin{array}{l}\text { Initiation } \\
\text { (hours) }\end{array} & \text { of } & \text { regular } & \text { diet } \\
\end{array}$} \\
\hline $12-24$ & $\begin{array}{l}18 \\
30\end{array}$ & $\begin{array}{l}30.0 \\
60.0\end{array}$ & $\begin{array}{c}0 \\
10\end{array}$ & $\begin{array}{c}0.0 \\
20.0\end{array}$ & 70.862 & $<0.001$ \\
\hline$>24$ & 2 & 4.0 & 40 & 80.0 & & \\
\hline Mean \pm SD & \multicolumn{2}{|c|}{$14.6 \pm 5.2$} & \multicolumn{2}{|c|}{$37.3 \pm 17.9$} & $9.154^{*}$ & $<0.001$ \\
\hline
\end{tabular}


Table (4): Distribution of the Women Undergoing Hysterectomy According to their Removal of Drain and Catheter as well as bowel mobility during the postoperative period $(\mathrm{N}=100)$

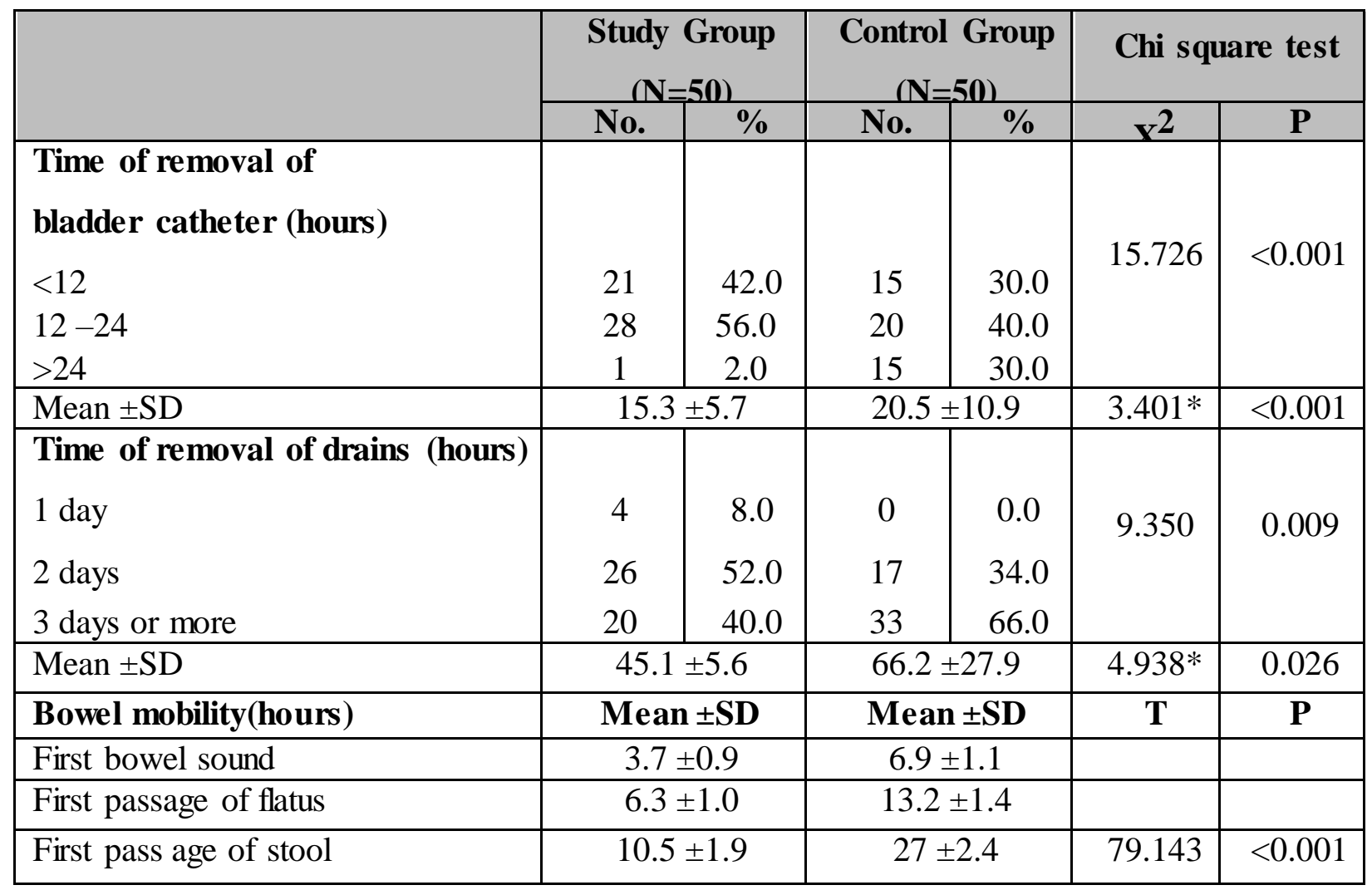

Table (5): Distribution of the Women Undergoing Hysterectomy According to the Postoperative Complications $(\mathrm{N}=100)$

\begin{tabular}{|l|c|c|c|c|c|c|}
\hline \multirow{2}{*}{ Variables } & \multicolumn{2}{|c|}{$\begin{array}{c}\text { Study Group } \\
\text { (N=50) }\end{array}$} & \multicolumn{2}{c|}{$\begin{array}{c}\text { Control Group } \\
\text { (N=50) }\end{array}$} & \multicolumn{2}{c|}{ Chi square test } \\
\cline { 2 - 7 } & No. & $\%$ & No. & $\%$ & $\mathbf{X}^{\mathbf{2}}$ & P \\
\hline Post-operative complications & & & & & & \\
No & 50 & 100.0 & 47 & 94.0 & 3.083 & 0.214 \\
1 & 0 & 0.0 & 1 & 2.0 & & \\
2 & 0 & 0.0 & 2 & 4.0 & & \\
\hline
\end{tabular}




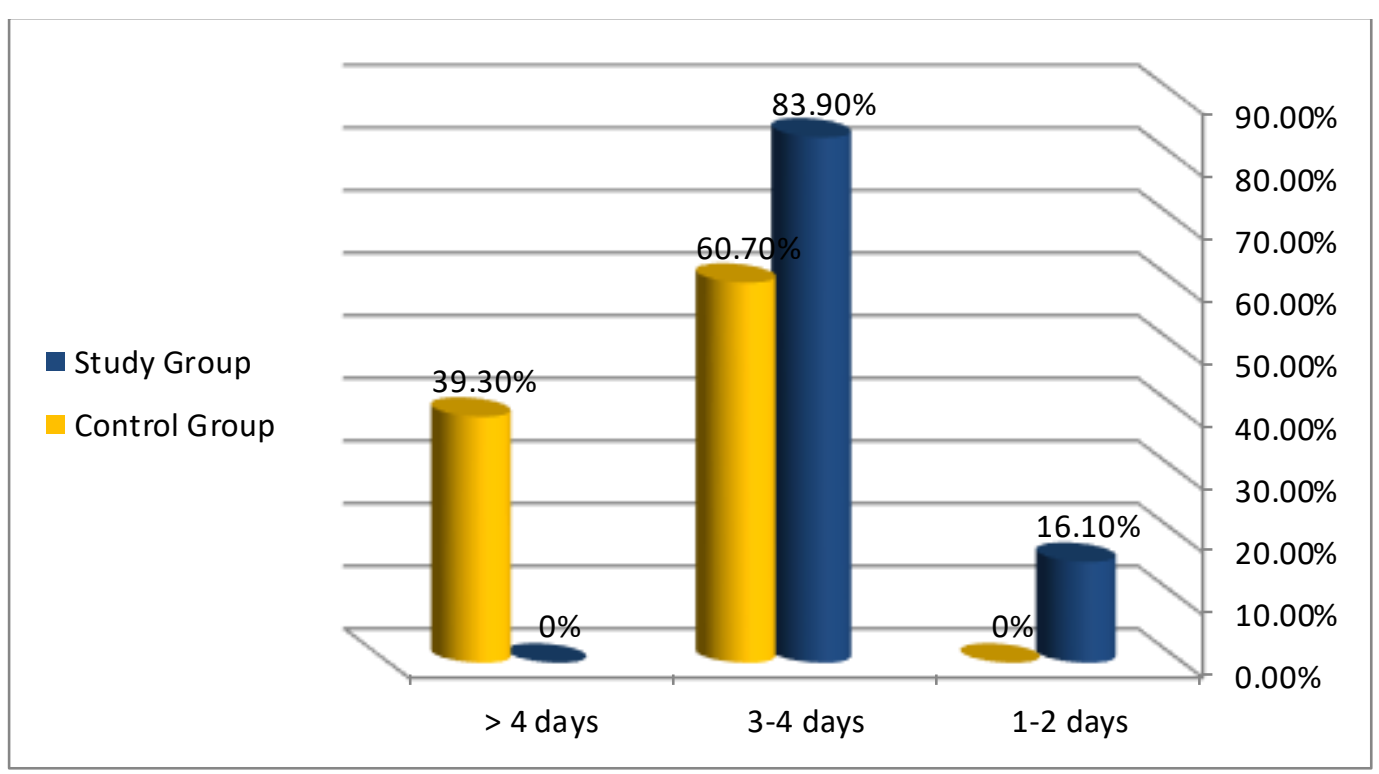

Figure(1): Description oflength ofstay among women inthestudy and control group.

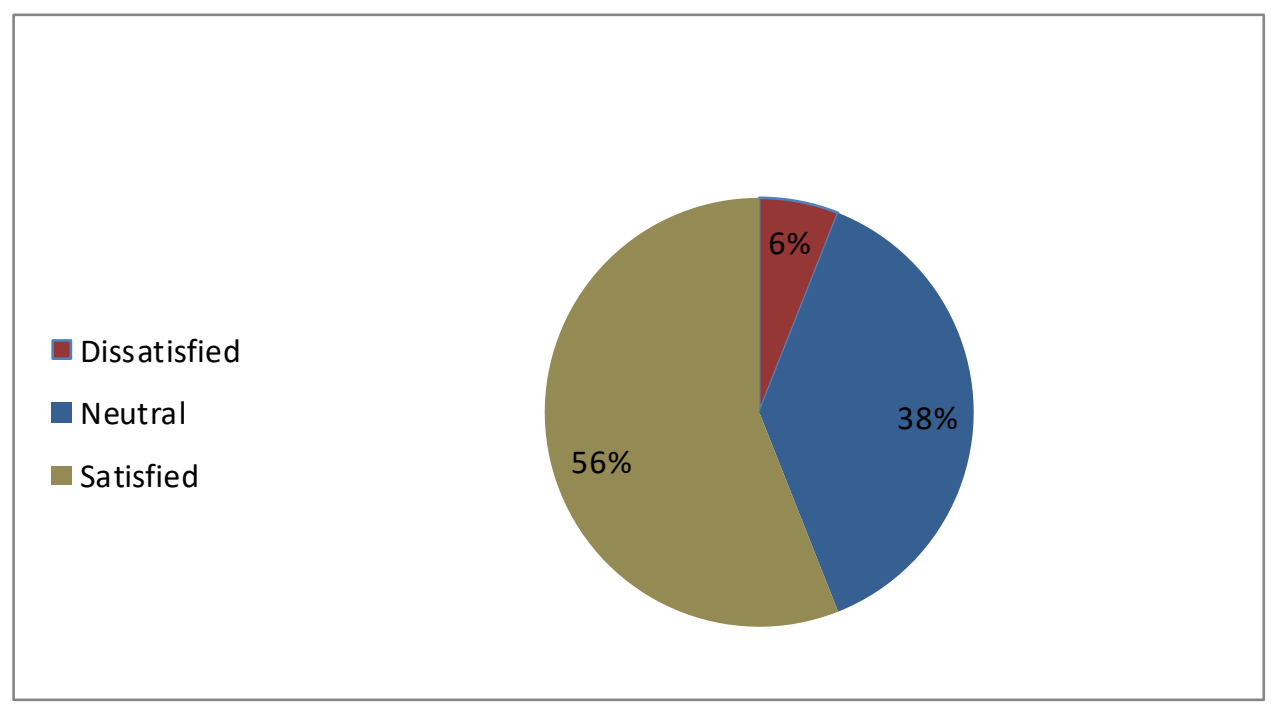

Figure(2): Distribution of women' total satisfaction 


\section{DISCUSSION :}

Clinical pathway management is a standardized, highly coordinated interdisciplinary preoperative surgical care program that in corporate evidence-based interventions to minimize surgical stress, improve physiological and functional recovery, reduce complications, and facilitate earlier discharge from the hospital and reduced cost of care (abd El-Razek, 2018). For implementation to be successful, nurses were found to be a key in providing education, perioperative care, and postoperative evaluation, as well as cost containment(Rotter, de Jong, Lacko, et al., 2019).

The key principles of the clinical path way management include; pre-operative counseling, preoperative nutrition, avoidance of perioperative fasting and carbohydrate loading up to2 hours preoperatively, standardized anesthetic and analgesic regimens(epidural and non-opioid analgesia)and early mobilization (El Baz et al., 2007).Studies have documented an association between the use of clinical guidelines and pathways and positive outcomes including the provision of high-quality, cost-effective care, greater patient and staff satisfaction, and better resource management in a variety of clinical contexts(Centre for Policy on Ageing,2021). Other studies have documented that the adoption of clinical pathways can reduce length of stay and decrease medical cost (Kinsman et al., 2010).

In order to investigate the extent to which the local hospital are adhering to national guidelines. The current research was undertaken to investigate the effect of clinical pathway of postoperative nursing care on improving postoperative outcomes for women undergoing hysterectomy. The study could provide beneficial ad valuable baseline information on the applying healthcare in hospital setting and the potential for enhancing in healthcare quality. Similarly,(Bai, Bai, Zhu and Xue, 2018)study has been conducted with the objectives of the using clinical pathways to enhance care given quality, to decrease financial costs, and to lower inappropriate difference in health care settings.

Evidence has shown that improper relief of postoperative pain has harmful physiological and psychological consequences for patients, increases morbidity, mortality and re-admission for pain management, extends hospitalization, and delays patients' return to their normal activities, with resulting increase in costs (Abd El-Razek, 2018).

Concerning the level of pain experienced by women during the postoperative period, the present result reveals that women in the study group experienced less mean score compared to those in the control group, thus they showed lesser need for analgesia with statistical significant difference. This could be attributed to alleviation of stress and 
clearing up misconceptions associated with hysterectomy surgery during the preoperative counseling (Schrijvers, Hoorn and Huiskes, 2012).

Concerning the length of stay, the present study finding has indicated that the mean duration of hospitalization in the study group was significantly shorter than those in the control group. This is supported by (Ghant et al., 2014) who found that clinical pathway management in women undergoing abdominal hysterectomy for benign disease had decreased median length of stay from 3 days to 1 day following implementation ( $\mathrm{p}<0.001$ ). Also, (DE BLESER et al., 2006)study who compared patients on clinical pathway management with those traditional control using a conventional protocol found that the median length of stay decreased from 3 to 2 days. Additionally in agreement with the above mentioned finding (Ghant et al., 2014)study included women with gynecologic malignancy in a retrospective study evaluating the implementation of clinical pathway management study in laparotomy for complex gynecologic surgery. They found that median length of stay was 4 days less in the clinical pathway management group than in the conventional group (8.7 vs. 11.9 days). Moreover, (DE BLESER et al., 2006)demonstrated that the mean length of stay length of stay was $4.29 \pm 2.78$ days for patients who followed clinical pathway management, significantly reduced compared to $7.23 \pm 5.68$ days for the control group $(\mathrm{p}<0.001)$.

The current study findings showed that patients underwent hysterectomy surgery in the study group were significantly more likely to have no vomiting compared to those in the control group. Thus less than one fifth of them were in need to anti emetic compared to almost half in the control group. This is supported by (Ibrahim, 2018) who found that about one third in the study group and about one half in the control group where in need for anti-emetics day 0 and $9 \%$ vs. $16 \%$ who received more than one dose.

Based on the present study findings, women in the study group were significantly more likely to start oral fluids within the first 10 hours after the surgery compared to those in the control group. Meanwhile, they received a higher mean amount of oral fluids and the majority of them begun regular diet within the first 24 hours after the surgery compared to those in the control group. Whereas (Schrijvers, Hoorn and Huiskes, 2012) demonstrated that time to tolerance of diet decreased by3days in the study group as compared to the control group. Meanwhile,(DE BLESER et al., 2006) showed that despite early feeding was associated with a higher rate of nausea and vomiting in the study group, $87 \%$ rated their satisfaction with nausea and vomiting control as excellent or very good, suggestingthat earlyfeedingis overall well tolerated. 
Significant differences in the postoperative bowel mobility were observed between the present study and the control groups. Women in the study group were more likely to have lesser mean time of first bowel sounds, first passage of flatus, and first defecation after surgery. In the same line(Hripcsak et al., 2016)reported that the experimental group significantly had earlier initiation of bowel sounds with a median value of 3 hours vs. 6.5 hours in the control group. Consequently the bowel movement returned significantly earlier with median duration of 29 hours among the study group compared to 54 hours amongthe controlgroup.

Concerning the time of removing bladder catheter and drains the present study reveals a statistically significant difference between the two groups $(\mathrm{p}<0.001)$. The mean time of removal of both drains was lesser in the study group than those in the control group. In the same line(DE BLESER et al., 2006) showed that early removal(1day) compared to standard removal(approximately 4days). In this respect (Ibrahim, 2018) mentioned that the foley catheters could be removed on postoperative day one for patients who have undergone laparoscopic procedures and by postoperative day two for patients who have under gone open abdominal procedures.

Women's satisfaction related to the care provided was assessed in the present study group (clinical path way nursing management). Thes core given was mostly satisfied and neutral. Similarly,(Abd El-Razek, 2018)reported that postoperative satisfaction was significantly higher inclinical pathway management group (82.8vs.71.7,p>0.001) than in the traditional group and suggested that clinical pathway management should be used after a complex gynecologic laparotomy.

\section{CONCLUSION}

\section{Based on study findings, the researchers can conclude:}

With the perspective of the impact of clinical pathway of postoperative nursing care on improving postoperative outcomes for women undergoing hysterectomy, the study findings showed that the clinical pathway was effective in improving postoperative outcomes as well as decreasing the incidence of complications in the post-operative period related to postoperative pain and need for analgesia, short length of hospital stay, early ambulation, early oral intake and patient satisfaction. These supported the research hypotheses. 


\section{RECOMMENDATIONS}

Based on the main findings we recommend that:

1- the clinical pathway management should be integrated in the postoperative management at governmental hospitals.

2- Health care setting should emphasize the importance of coordination between health care members relating to the application of the evidenced key elements of clinical pathway management.

3- Ongoing in-service training programs are recommended for maternity nurses in order to enhance their knowledge and practice regarding clinical pathway management.

4- Further studies are recommended using different protocol of management with different evidence based practices, with a larger sample size and in different setting.

\section{REFERENCES}

Aarts, J., Nieboer, T., Johnson, N., Tavender, E., Garry, R., Mol, B. and Kluivers, K., 2015. Surgical approach to hysterectomy for benign gynaecological disease. Cochrane Database of Systematic Reviews,.

Abd El-Razek, A., 2018. Effect of Implementing Clinical Pathway to Improve Child-Birth and Neonatal Outcomes. American Journal of Nursing Research, 6(6), pp.454465.

Al-Hendy, A., Myers, E. and Stewart, E., 2017. Uterine Fibroids: Burden and Unmet Medical Need. Seminars in Reproductive Medicine, 35(06), pp.473-480.

Bai, J., Bai, F., Zhu, H. and Xue, D., 2018. The perceived and objectively measured effects of clinical pathways' implementation on medical care in China. PLOS ONE, 13(5), p.e0196776.

Borah, B., Laughlin-Tommaso, S., Myers, E., Yao, X. and Stewart, E., 2016. Association Between Patient Characteristics and Treatment Procedure Among Patients With Uterine Leiomyomas. Obstetrics \& Gynecology, 127(1), pp.67-77.

Cdc.gov. 2021. Inpatient Surgery.CDC/National Center for Health Statistics. [online] Available at: <https://www.cdc.gov/nchs/fastats/inpatientsurgery.htm> [Accessed 24 September 2017]. 
Chinese Ministry of Health and Family Planning. NCMS Progress in 2012 and key work in 2013. Chinese Ministry of Health and Family Planning.[online] Available at: <http://wwwnhfpcgovcn/jws/hzyl/list_3shtml> [Accessed 27 January 2021].

Cpa.org.uk. 2015. The effectiveness of care pathways in health and social care. [online] Available at: <http://www.cpa.org.uk/information/reviews/CPA-Rapid-ReviewEffectiveness-of-care-pathways.pd $>$ [Accessed 27 January 2021].

De bleser, L., Depreitere, R., Waele, K., Vanhaecht, K., Vlayen, J. and Sermeus, W., 2006.Defining pathways. Journal of Nursing Management, 14(7), pp.553-563.

Desai, S., Campbell, O., Sinha, T., Mahal, A. and Cousens, S., 2016. Incidence and determinants of hysterectomy in a low-income setting in Gujarat, India. Health Policy and Planning, 32(1), pp.68-78.

El Baz, N., Middel, B., van Dijk, J., Oosterhof, A., Boonstra, P. and Reijneveld, S., 2007. Are the outcomes of clinical pathways evidence-based? A critical appraisal of clinical pathway evaluation research. Journal of Evaluation in Clinical Practice, 0(0), p.070821070410002-???.

Gandaglia, G., Ghani, K., Sood, A., Meyers, J., Sammon, J., Schmid, M., Varda, B., Briganti, A., Montorsi, F., Sun, M., Menon, M., Kibel, A. and Trinh, Q., 2014.Effect of Minimally Invasive Surgery on the Risk for Surgical Site Infections. JAMA Surgery, 149(10), p.1039.

Ghant, M., Lawson, A., Sengoba, K., Recht, H., Mendoza, G., McGuire, J. and Marsh, E., 2014. Beyond the physical: a qualitative assessment of the emotional burden of symptomatic uterine fibroids on women's mental health. Fertility and Sterility, 102(3), p.e248.

Healthwise. 2021. Award-winning health content innovative technology solutions. [online] Available at: <https $/ /$ www.healthwise.org/about.aspx> [Accessed 24 September 2017].

Hripcsak, G., Ryan, P., Duke, J., Shah, N., Park, R., Huser, V., Suchard, M., Schuemie, M., DeFalco, F., Perotte, A., Banda, J., Reich, C., Schilling, L., Matheny, M., Meeker, D., Pratt, N. and Madigan, D., 2016. Characterizing treatment pathways at scale using the OHDSI network. Proceedings of the National Academy of Sciences, 113(27), pp.7329-7336. 
Ibrahim, Z., 2018. Effect of the use of Clinical Pathway for Patients with Unstable Angina on Nursing Performance and Patient's Outcomes. Assiut Scientific Nursing Journal, 6(14), pp.81-87.

Jabbour, M., Curran, J., Scott, S., Guttman, A., Rotter, T., Ducharme, F., Lougheed, M., McNaughton-Filion, M., Newton, A., Shafir, M., Paprica, A., Klassen, T., Taljaard, M., Grimshaw, J. and Johnson, D., 2013. Best strategies to implement clinical pathways in an emergency department setting: study protocol for a cluster randomized controlled trial. Implementation Science, 8(1).

Kinsman, L., Rotter, T., James, E., Snow, P. and Willis, J., 2010. What is a clinical pathway? Development of a definition to inform the debate. BMC Medicine, 8(1).

Laberge, P., Singh, S., Lamontagne, A. and Vilos, G., 2017. Disease Burden Among Canadian Women With Symptomatic Uterine Fibroids: Interim Results of CAPTURE [1H]. Obstetrics \& Gynecology, 129(1), pp.81S-82S.

Liu, F., Guo, F., Zhou, Y., He, Z., Tian, X., Guo, C., Ning, T., Pan, Y., Cai, H. and Ke, Y., 2012. The Anyang Esophageal Cancer Cohort Study: Study Design, Implementation of Fieldwork, and Use of Computer-Aided Survey System. PLoS ONE, 7(2), p.e31602.

Mansuria, S., Comerci, J., Edwards, R., SaneiMoghaddam, A., Ma, T. and Linkov, F., 2016. Changes in Hysterectomy Trends and Patient Outcomes Following the Implementation of a Clinical Pathway [7]. Obstetrics \& Gynecology, 127(Supplement 1), p.3S.

Qualtrics Survey Service. [online] Available at: $<$ https://www.technology.pitt.edu/service/qualtricssurvey-service> [Accessed 24 September 2017].

Rotter T, de Jong RB, Lacko SE, et al., 2019. Clinical pathways as a quality strategy. In: Busse R, Klazinga N, Panteli D, et al, editors. Improving healthcare quality in Europe: Characteristics, effectiveness and implementation of different strategies [Internet].

Copenhagen (Denmark): European Observatory on Health Systems and Policies. (Health Policy Series, No. 53.) 12. Available from: https //www.ncbi.nlm.nih.gov/books/NBK549262/ 
Rotter, T., Kugler, J., Koch, R., Gothe, H., Twork, S., van Oostrum, J. and Steyerberg, E., 2008. A systematic review and meta-analysis of the effects of clinical pathways on length of stay, hospital costs and patient outcomes. BMC Health Services Research, 8(1).

Sarna, A., Friedland, B., Srikrishnan, A., Katzen, L., Tun, W., Abbott, S., Rawiel, U., Kelly, C., Shalini, C., Solomon, S. and Mensch, B., 2013. Sexually transmitted infections and reproductive health morbidity in a cohort of female sex workers screened for a microbicide feasibility study in Nellore, India. Global Journal of Health Science, 5(3).

Schrijvers, G., Hoorn, A. and Huiskes, N., 2012. The Care Pathway Concept: concepts and theories: an introduction. International Journal of Integrated Care, 12(6).

Stang, A., Kluttig, A., Moebus, S., Völzke, H., Berger, K., Greiser, K., Stöckl, D., Jöckel, K. and Meisinger, C., 2014. Educational level, prevalence of hysterectomy, and age at amenorrhoea: a cross-sectional analysis of 9536 women from six population-based cohort studies in Germany. BMC Women's Health, 14(1).

Wright, J., Anath, C., Lewin, S., Burke, W., Lu, Y., Neugut, A., Herzog, T. and Hershman, D., 2013. Robotically Assisted vs Laparoscopic Hysterectomy Among Women With Benign Gynecologic Disease. Survey of Anesthesiology, 57(4), pp.203-204.

Wright, J., Herzog, T., Tsui, J., Ananth, C., Lewin, S., Lu, Y., Neugut, A. and Hershman, D., 2013. Nationwide Trends in the Performance of Inpatient Hysterectomy in the United States. Obstetrics \& Gynecology, 122(2), pp.233-241.

Yamazaki, T. and Umemoto, K., 2010.Knowledge Management of Healthcare by Clinical-Pathways. Journal of Information \& Knowledge Management, 09(02), pp.119-125.

Yeh, J., Cheng, H., Hsu, P., Sung, S., Liu, W., Fang, H. and Chuang, S., 2013. Hysterectomy in young women associates with higher risk of stroke: A nationwide cohort study. International Journal of Cardiology, 168(3), pp.2616-2621. 


\section{تأثير المسار السريري للرعاية التمريضية بعد الجراحة في تحسين نتائج ما بعد الجراحة للنساء اللواتي يخضعن لاستئصال الرحم}

\section{الخلاصة}

استخدام المسار السريري متعدد التخصصات أثناء رعاية النساء اللواتي يخضعن لاستنئصال الرحم يكون أكثر فعالية من الرعاية التمريضية الروتينية في المستشفى. الهدف: أجريت هذه الدراسة لمعرفة تأثثر المسار السريري للرعاية

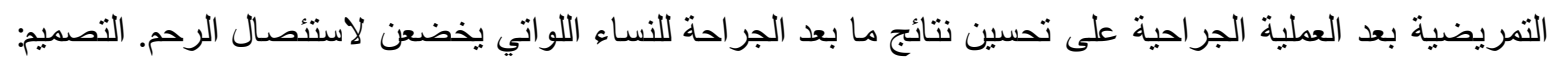
تصميم شبه تجريبي (مجموعة دراسة وضابطة). مكان الدراسة: أقسام أمراض النساء و التوليد باللمستشفى الجامعي ومستشفى شبين الكوم التعليمي بمحافظة المنوفية. العينة: تم اختيار 100 امر أة تخضع لعملية استنُصال الرحم. الأدوات:

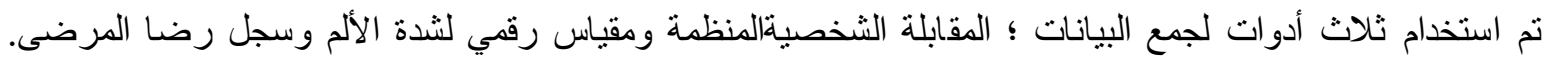
النتائج: أظهرت الدراسة الحالية أن النساء اللواتي خضعن لاستئصال الرحم في مجموعة الدراسة كن أكثر عرضة بشكل ملحوظ لتجربة متو سط درجات الألم الأقل ، والحاجة الأقل للتسكين ولوحظت اختلافات كبيرة في مدة الإقامة مقارنة مع أولئك في المجموعة الضابطة. لوحظت ايضا اختلافات كبيرة في تناول الاكل عن طريق الفم في وقت مبكر

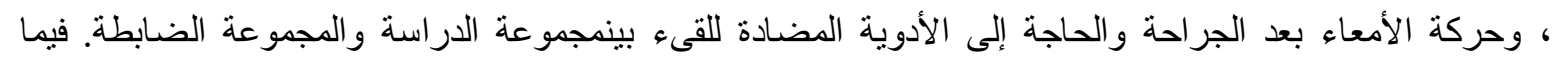
يتعلق برضاء السيداتعن الرعاية المقدمة ، كانت الدرجة الممنوحة كانت في الغالب بين راضية ومحايدة. الخلاصنة: كان النداء تنفيذ المسار السريري ناجحًا في تحسين الألم بعد الجراحة ، وقصر مدة البقاء بعد الجراحة ، و المشي المبكر ، وتناول الغذاء بالفم المبكر ، وحركة الأمعاء ، بجانب قصر مدة إزالة القسطرة والدرنقة وزيادة رضاء المريض. توصية: يوصى بتعميم تنفيذ المسارات السريرية في البيئات السريرية الأخرى لتحسين نتائج المرضى وتقليل مضاعفات ما بعد ودئ الجر احة.

الكلمات المرشدة : استئصسال الرحم ، المسار السريري ، رعاية تمريضية ، نتائج ما بعد الجراحة 